Crop Breeding and Applied Biotechnology 13: 228-233 2013

Brazilian Society of Plant Breeding. Printed in Brazil

\title{
ARTICLE
}

\section{Cytological characterization of Jatropha curcas callus in different periods of cultivation}

Dalilhia Nazaré dos Santos ${ }^{1 *}$, Claudinéia Ferreira Nunes ${ }^{1}$, Joyce Dória Rodrigues Soares ${ }^{1}$, Thaís Cainã Teixeira Valente ${ }^{2}$, Eduardo Alves ${ }^{2}$, Cláudia Regina Gontijo Labory ${ }^{2}$ and Moacir Pasqual ${ }^{1}$

Received 04 February 2013

Accepted 17 October 2013

\begin{abstract}
The aimed was characterization and determining the time for Jatropha curcas callus subculture. The pattern of J. curcas callus development is sigmoidal with 5 distinct phases, and transplantation should be performed at the end of the deceleration phase (approximately day 28). During callus development, it was observed that at the onset of growth in the exponential phase the cells were internally disorganized; in the linear phase, respiratory metabolism was resumed through reorganization of the first mitochondria; and by the mid-deceleration phase, the cells were entirely active, and several organelles were detected. This organizational status was maintained throughout the stationary phase during which somatic pre-embryos were identified. At the end of the stationary phase, intracellular disruption began, and the cells entered senescence, which characterized the decline phase for the J. curcas calli growth curve.
\end{abstract}

Key words: In vitro, kinetics and ultrastructure.

\section{INTRODUCTION}

The demand for alternative sources of energy is global, and alternative fuels, such as bioethanol and biodiesel, may relieve the problems caused by fossil fuel consumption. Among the available oil-producing plants, J. curcas has been gaining agronomic importance, which is demonstrated by recent cytogenetic characterization (Carvalho et al. 2008, Dahmer et al. 2009) and genome sequencing (Sato et al. 2010) that facilitate more applied research with this species.

Tissue culture represents an area of biotechnology research that has significantly progressed for $J$. curcas. The first reports of the cultivation of $J$. curcas in vitro get along with Sujatha and Mukta (1996), which tested various explants, including leaves, petioles and hypocotyls in $0.5 \mathrm{mg}$ $\mathrm{L}^{-1} \mathrm{BAP}$ (benzylaminopurine) and $1.0 \mathrm{mg} \mathrm{L}^{-1} \mathrm{IBA}$ (indolebutyric acid). A recently published patent (US 7,932,086 B2) disclosed micropropagation of $J$. curcas on a commercial scale (Murali et al. 2011). Further, according to Leela et al. (2011) and Sharma and Chauhan (2011), micropropagation of $J$. curcas produces genetically stable plants when it is limited to seven subcultures. Therefore, tissue culture for $J$. curcas micropropagation is in the process of consolidation (Sardana et al. 2000, Jha et al. 2007, Nunes et al. 2008).
An additional sub-area for further research is in vitro regeneration because it is the technique that regenerates organs and tissues in transformed plants; this technique has been used in J. curcas studies with both biolistic and Agrobacterium transformation (Joshi et al. 2011, Misra et al. 2011).

In vitro regeneration has several restrictions including subculture timing in pathways mediated by callus. This information is often not fully elucidated in manuscripts on in vitro regeneration of $J$. curcas (Qin et al. 2004, Kaewpoo and Te-Chatob 2009, Kumar and Reddy 2010, Kumar et al. 2011); therefore, the average subculture time should be determined for the morphogenetic processes in this species.

The callus growth curve is a functional tool that provides the average time for subculturing, which is useful because in the upward growth phase of the curve, cells have a high capacity for division, and after this period, they enter the stationary phase. In the stationary phase, a high number of cells have a lower capacity for division, and these cells enter the cell differentiation stage (Pereira et al. 2007). Therefore, using the callus growth curve, the crop transplantation time can be identified in addition to the best phases to determine development kinetics and maximize cell replication (Abbade et al. 2010).

\footnotetext{
${ }^{1}$ Universidade Federal de Lavras (UFLA), Departamento de Agricultura, CP 3037, 37.200-000, Lavras, MG, Brasil. *E-mail: dalilhia@yahoo.com.br

${ }^{2}$ UFLA, Departamento de Fitopatologia
} 
The callus growth curve can also assist in monitoring development when it is linked to an additional tool, such as electron microscopy. According to Fernando et al. (2007), electron microscopy is a valuable tool used to elucidate the in vitro regeneration process.

There are only brief reports of electron microscopy use for $J$. curcas, with only two records being available in the literature. The first describes the morphological differences between browning and non-browning $J$. curcas calli cultured in vitro (He et al. 2009), and the latter characterizes flower development in J. curcas (Wu et al. 2011). There are no reports in which electron microscopy was used to discern the morphogenetic processes for $J$. curcas, and according to Varshney et al. (2011), this approach would significantly contribute to elucidating an in vitro culture system.

Consequently, the study herein uses techniques and tools to determine and reduce the callus mass incubation periods as well as to investigate their development and improve morphogenetic success. Thus, the study herein was aimed at determining the time for $J$. curcas callus subculture using the callus growth curve and monitoring their development by evaluating cellular and intracellular characteristics using ultrastructural analyses.

\section{MATERIAL AND METHODS}

\section{Plant material}

The experiment described herein was conducted in the Plant Tissue Culture Laboratory of the Department of Agriculture at the Federal University of Lavras (Laboratório de Cultura de Tecidos Vegetais do Departamento de Agricultura da Universidade Federal de Lavras, UFLA).

The $J$. curcas seeds were generated in vitro using the method developed by Nunes et al. (2008) to produce a seedling with fully expanded cotyledons. The cotyledons were cut into $1 \mathrm{~cm}^{2}$ segments using a scalpel in a sterile laminar flow hood, inoculated in an MS medium (Murashig and Skoog 1962), prepared by adding $30 \mathrm{~g} \mathrm{~L}^{-1}$ of saccharose supplemented with $1 \mathrm{mg} \mathrm{L}^{-1}$ of 2,4-D (2,4-dichlorophenoxyacetic acid), solidified with $5.5 \mathrm{~g} \mathrm{~L}^{-1}$ of agar, and then autoclaved at $121^{\circ} \mathrm{C}$ for $20 \mathrm{~min}$ at $1 \mathrm{~atm}$. The cultures were stored in a metal cabinet to ensure complete darkness in a growth chamber at $25 \pm 2{ }^{\circ} \mathrm{C}$.

The experiment followed a randomized design and was statistically analyzed using the Regression test with the Sisvar software (Ferreira 2011).

\section{Callus growth curve}

The $J$. curcas calli were subcultured twice at 30-day intervals to ensure that the final explant for inoculation was a genuine callus with no leaf tissue. The callus growth curve was established after the second subculture by inoculating the aggregates in a medium with $0.29 \mathrm{~g}$ of fresh matter. They were then weighed for 112 days at seven-day intervals beginning at inoculation.

The experimental design was completely randomized with 16 treatments, consisting of the evaluation intervals $(0,7,14,21,28,35,42,49,56,63,70,77,84,91,98,105$ and 112 days). Therefore, growth at 16 time periods was determined and characterized at the assessment intervals using three replicates; each replicate was an average of three tubes, and each tube contained one explant. The growth curve was plotted using the average of three replicates for each mass assessment. Concomitantly, the callus masses were evaluated ultrastructurally using transmission electron microscopy (TEM) and scanning electron microscopy (SEM) for each growth period.

\section{Ultrastructural analysis}

To prepare and observe the samples for TEM and SEM, approximately $1 \mathrm{~cm}^{2}$ sections from a callus mass were cut from each treatment and immersed in Karnovsky's fixative (modified Karnovsky's fixative, 2.5\% glutaraldehyde, 2.5\% formaldehyde in $0.05 \mathrm{M}$ sodium cacodylate buffer, $\mathrm{pH} 7.2$ and $0.001 \mathrm{M} \mathrm{CaCl}_{2}$ ) for $24 \mathrm{~h}$. Subsequently, the samples were pre-fixed in aldehyde and washed three times in 0.05 $\mathrm{M}$ cacodylate buffer for approximately $10 \mathrm{~min}$ and then immersed in $1 \%$ osmium tetroxide $\left(\mathrm{OsO}_{4}\right)$ in $0.05 \mathrm{M}$ cacodylate buffer $\mathrm{pH} 7.2$ for $1 \mathrm{~h}$ at room temperature in a fume hood. The samples fixed in $\mathrm{OsO}_{4}$ were washed with distilled water and added to solutions with increasing acetone concentrations $(25,50,75,90$ and $100 \%)$ for dehydration. They remained in each solution for approximately $10 \mathrm{~min}$; however, they were immersed in the $100 \%$ solution three times.

For the TEM analysis, after dehydration in acetone, the samples were embedded in $30 \%$ and $70 \%$ resin for 8 $\mathrm{h}$ and $12 \mathrm{~h}$, respectively. Subsequently, the samples were twice added to a $100 \%$ resin for $24 \mathrm{~h}$ each; the material was placed in a suitable mold, and it polymerized in an oven at $70^{\circ} \mathrm{C}$ for $48 \mathrm{~h}$. After ultramicrotomy, the ultra-thin sections were transferred to screens and contrasted using uranyl acetate and lead citrate. A Zeiss EM 109 Transmission Electron Microscope was used for observations and electron microscopy analysis.

For the SEM analysis, the material was dried in the critical point apparatus, the stubs were mounted, and the material was sputter-coated with gold. The prepared leaf material was observed, and electron micrograph images were taken using the Leo Evo 40 SEM. 


\section{RESULTS AND DISCUSSION}

The kinetic pattern for a callus growth curve is sigmoidal and comprises lag, exponential, linear, deceleration, and stationary phases. This behavior was observed in several woody species, such as Bertholletia excelsa (Serra et al. 2000) and Byrsonima intermedia A. Juss. (Abbade et al. 2010). However, not all phases are necessarily observed; for example, Stein et al. (2010) did not identify the stationary phase in the Inga vera Willd callus.

For J. curcas, the lag phase was absent, and the decline phase was identified. Thus, J. curcas has five callus development phases: exponential, linear, deceleration, stationary, and decline (Figure 1).

A lag phase was not identified in the callus growth curve for $J$. curcas. As this is the preparation phase for cell division, it likely spanned less than 7 days and, consequently, was not identified because the assessment intervals were 7-days long. A secondary explant (callus) was used for kinetic evaluation because it had begun dividing. For example, Serra et al. (2000) demonstrated that the lag phase is extended when a leaf is used as the initial explant using $B$. excelsa leaves to initiate a growth curve and detecting a 30-day lag phase.

The callus growth curve for $J$. curcas began with an exponential phase in which cell division was already pronounced, and it remained in this phase from days 0 to 7 . In contrast, the callus growth curve begins with the lag phase for B. intermedia (Abbade et al. 2010).

The linear growth period in which the calli decrease the rate of cell division and increase cellular area (Smith 1992) was observed between days 7 and 14. This brief period is due to the homogenous tissue, as it is a secondary explant

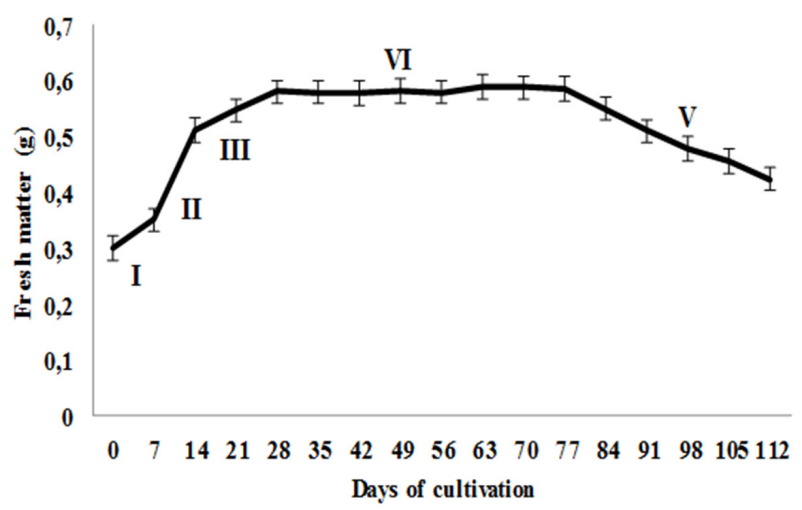

Figure 1. The callus growth curve from data obtained using Jatropha curcas leaf explants inoculated in MS medium supplemented with $1.0 \mathrm{mg}$ $\mathrm{L}^{-1}$ of 2,4-D. I. exponential growth phase (0-7 days); II. linear phase (7-14 days); III. deceleration phase (14-28 days); IV. stationary phase (28-77 days); and V. decline phase (after 77 days).
(Serra et al. 2000).

The deceleration phase composes the period from days 14 to 28 . According to Smith (1992), calli must be subcultured during the deceleration phase because the cells do not divide by the mid-stationary phase. Therefore, J. curcas calli should be subcultured approximately 28 days after growth.

The stationary phase continued until day 77 . It is worth noting that in this phase, growth ceased, but the development processes, such as differentiation, were active. At day 84, the $J$. curcas calli entered the decline phase, wherein development also ceased because the callus was in senescence.

Using TEM during the $J$. curcas callus growth curve, large vacuoles and a thin cell wall were observed from the day of inoculation to 7 days later (exponential phase). In general, the cells had few organelles, a disorganized cellular system, and a narrow cytoplasm, which the vacuole compressed against the cell wall (Figure 2a-b). According to Lodish et al. (2000), a low number of organelles was also reported for $B$. intermedia with embryogenic calli, which is characteristic of meristematic or embryonic cells during growth. Canhoto et al. (1996) also observed cytoplasm compression by the vacuole in cells with pro-embryogenic
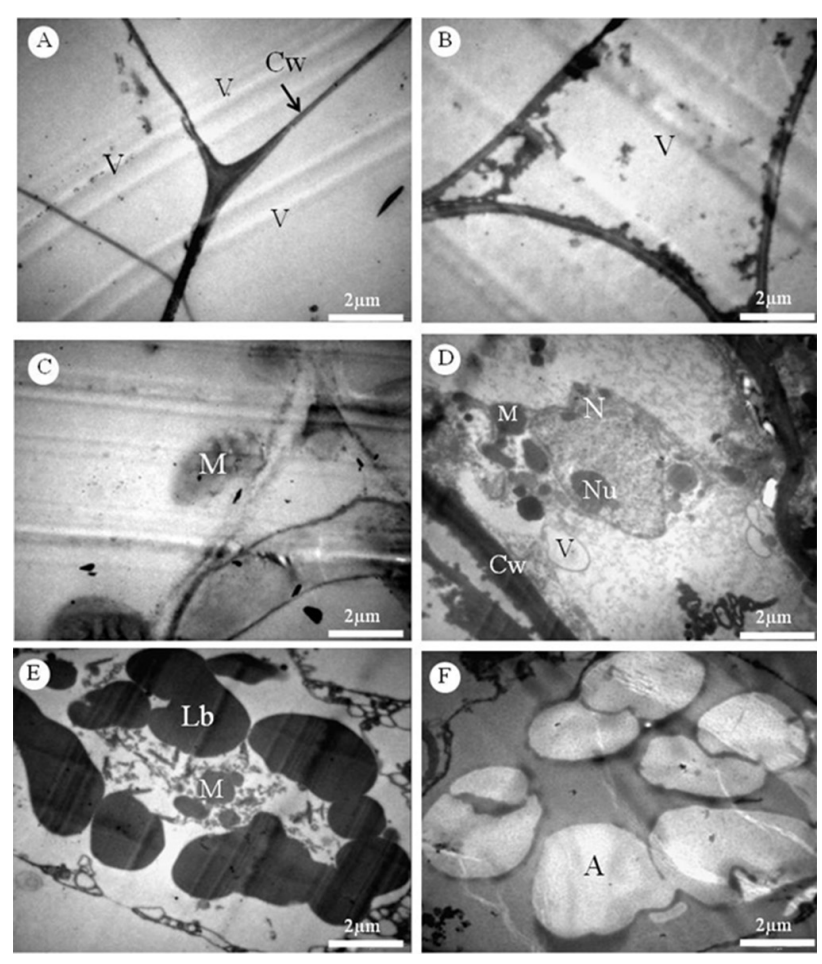

Figure 2. Electron micrographs of Jatropha curcas calli developed using 1 $\mathrm{mg} \mathrm{L}^{-1}$ of 2,4-D. a-b: exponential growth phase (0-7 days), large vacuoles (v) and a thin cell wall (Cw). c-d: deceleration phase (14-28 days), mitochondria (M) likely with cristae and fully organized cell with a nucleus $(\mathrm{N})$, nucleolus $(\mathrm{Nu})$, mitochondria $(\mathrm{M})$, vacuole $(\mathrm{V})$ and cell wall $(\mathrm{Cw})$. e-f: stationary phase (28-77 days), lipid bodies (LB) and f amyloplasts (A). 
characteristics.

After 7 days of growth, cellular evolution was observed. The nucleus took shape, and at the end of the linear phase, the mitochondria formed, which demonstrated that respiratory metabolism in the callus mass was activated. Functional respiratory metabolism is important because the saccharose previously added to the culture medium is incorporated in glycolysis through respiration. Saccharose catabolism into smaller sugars produces the ATP needed to meet the cell's energy demand for its anabolic processes. With active respiratory metabolism in the callus, cell division is resumed, which renews the cellular complex in the callus mass. Thus, the linear growth phase in the J. curcas callus growth curve was observed during this period (7 days).

During the mid-deceleration phase (21 days), fully developed mitochondria were detected, and the mitochondrial cristae were visualized, which is key for aerobic respiration because it is where certain electron transport and ATP synthesis reactions occur (Figure 2c). The mitochondrial matrix, which contains several enzymes and other compounds involved in the Krebs cycle, is in the space enclosed by the inner membrane. The Krebs cycle is also essential for aerobic respiration because it generates $\mathrm{NADH}$ and $\mathrm{FADH}_{2}$, which are precursors used in the electron transport chain (Semenza 2007).

Over time, the organizational status of entire cell improved. At the end of the deceleration phase (28 days), the nucleus contained a prominent nucleolus, mitochondria, small vacuoles, and a thick cell wall (Figure 2d). A thick wall indicates a decreased rate of cell division. According to Evert (2006), thick walls may hinder (retard and even prevent) cell division, which explains the stationary growth period observed for the $J$. curcas callus growth curve at the end of the deceleration phase. In this phase, lipid bodies were also observed (Figure 2e), which may function as reserves and can be converted into glucose as a substrate for respiration, which is commonly observed in seeds (Evert 2006).

Notably, the complete organizational status of the cell at 28 days validates the subculture period suggested by the $J$. curcas callus curve, and this approach can only be used when the organizational status of the cell is complete.

The intracellular characteristics generated during the deceleration phase were maintained throughout the stationary phase, and only at the end of this phase (after 77 days) was cellular disarray observed with many amyloplasts (Figure 2f). Häsler et al. (2003) also observed many amyloplasts in cells cultured in vitro for long periods and linked this observation to loss of cell regenerative capacity. Thus, long growth periods are disadvantageous for the $J$. curcas species because the crop loses vitality. A long growth period was only used herein because it was required for the experiment.

The SEM photomicrographs show dense aggregates around the linear growth phase with primarily spherical cells. According to Na et al. (2007), both of these characteristics are typical for embryogenic cells; non-embryogenic complexes show the opposite characteristics (Figure 3a-b). The $J$. curcas calli form such aggregates because the inoculated callus mass is from two subcultures in MS medium that contains $1 \mathrm{mg} . \mathrm{L}^{-1}$ de 2,4-D, which is a regulator that induces somatic embryogenesis (Zuo et al. 2002, George et al. 2008).

Through the end of the stationary phase, the cellular characteristics observed using this tool were the same as described previously, and at day 77, evidence of embryogenesis was observed, as the development process included two of the first phases of somatic embryo differentiation, the globular and cordiform embryo stages (Figure 3c-f). These structures did not continue to develop because the cells entered the decline phase, and as shown by TEM, they lost organization at the intracellular level due to senescence. The other stages of somatic embryo differentiation could be observed by following the methodological precepts for somatic embryogenesis, such as transferring the pre-embryos
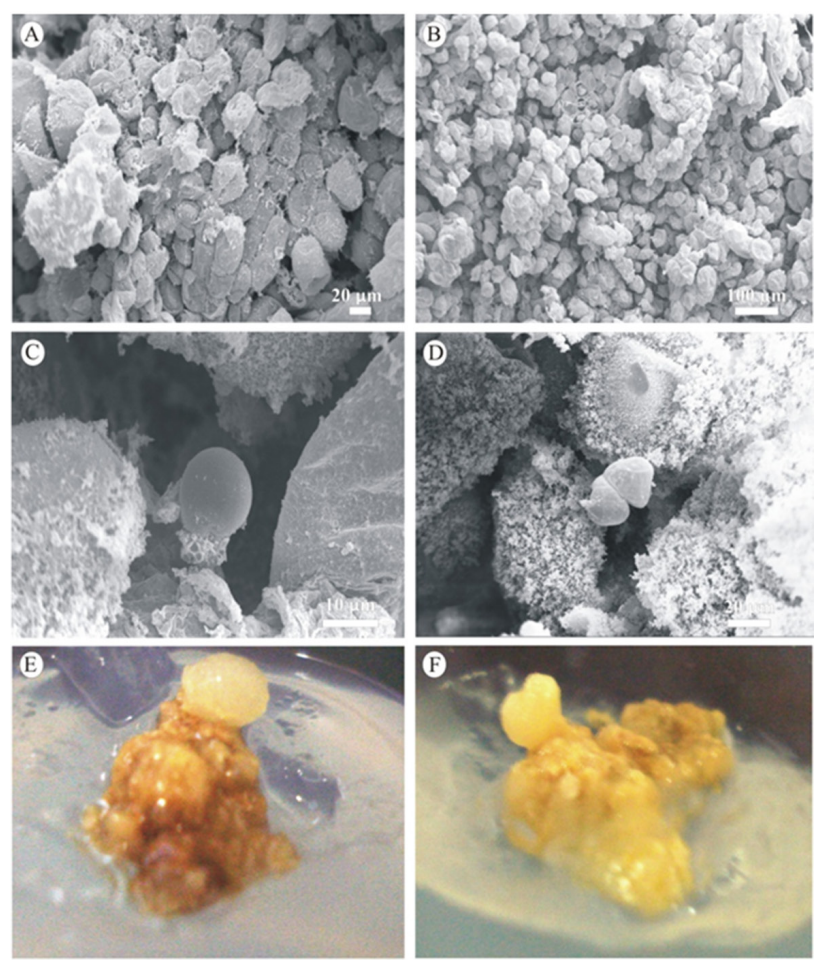

Figure 3. Jatropha curcas callus developed with $1 \mathrm{mg} \cdot \mathrm{L}^{-1}$ of 2,4-D. a-b: exponential growth phase (0-7 days), electron micrograph of the cells are isodiametric on the day of inoculation. c-e: stationary phase (28-77 days), details of the somatic embryos during the globular and cordiform stages. 
to a suitable medium; however, this was not the main focus for the research herein.

Thus, using the analytical tools discussed herein, the callus growth curve was measured, and it was established that $J$. curcas callus masses should be subcultured at approximately day 28 of growth. TEM was used to validate this conclusion, as it showed that the cell was not completely organized during the earlier stages, and at later stages, the cell reached a stable phase and then senesced. By subculturing at approximately day 28 , the morphogenetic expression potential of $J$. curcas callus can be explored.

J. curcas has five development phases and should be subcultured at the end of the deceleration phase (approximately day 28). At the onset of growth, cells from the $J$. curcas callus mass were disorganized at the intracellular level.
Beginning with the linear phase, respiratory metabolism resumed function by restructuring the first mitochondria; at the end of the deceleration phase, all of the organelles were observed to be present, and full cellular activity was resumed. On average, this level of cellular organization is maintained for over 56 days, during which somatic preembryos were identified. After 84 days, the $J$. curcas callus cells senesced.

\section{ACKNOWLEDGEMENTS}

The authors would like to thank the National Council for Scientific and Technological Development (Conselho Nacional de Desenvolvimento Científico e Tecnológico, $\mathrm{CNPq}$ ) and the Brazilian Federal Agency for Support and Evaluation of Graduate Education (Coordenação de aperfeiçoamento de Pessoal de Nível Superior, CAPES).

\section{Caracterização citológica de calos de Jatropha curcas L. em diferentes períodos de cultivo}

Resumo - Determinou-se o tempo de subcultivo de calos de Jatropha curcas. Uma curva de crescimento dos calos foi estruturada por 16 períodos de cultivo e para cada período foi feita análise ultraestrutural em microscopia eletrônica de transmissão e varredura. $O$ padrão de desenvolvimento dos calos de J. curcas é uma sigmóide com cinco fases é é ao final da desaceleração que deve ser realizada a repicagem, em média aos 28 dias de cultivo. No início do cultivo dos calos, na fase exponencial, as células estão desorganizadas subcelularmente; na fase linear é retomado o metabolismo respiratório por reestruturação das primeiras mitocôndrias, e em meados da fase de desaceleração as células estão completamente ativas, podendo se detectar várias organelas. Este nível organizacional se mantém por toda a fase estacionária, durante a qual pré-embriões somáticos foram identificados. Ao final da fase estacionária começa a desestruturação subcelular, as células entram em processo de senescência, caracterizando a fase de declínio da curva de crescimento de calo de J. curcas.

Palavras-chave: In vitro, cinetina e ultraestrutura.

\section{REFERENCES}

Abbade LC, Paiva PDO, Paiva R and Graciano MHP (2010) Growth curve and biochemical analyses of callus of ipê-branco (Tabebuia roseo alba (Ridl.) Sand). Naturale 33: 45-56.

Canhoto JM, Mesquita JF and Cruz GS (1996) Ultrastructural changes in cotyledons of pineapple guava (Myrtaceae) during somatic embryogenesis. Annals of Botany 78: 513-521.

Carvalho CR, Clarindo WR, Praça MM, Araújo FS and Carels N (2008) Genome size, base composition and karyotype of Jatropha curcas L., an important biofuel plant. Plant Science 174: 613-617.

Dahmer N, Wittmann MTS and Dias LAS (2009) Chromosome numbers of Jatropha curcas L.: an important agrofuel plant. Crop Breeding and Applied Biotechnology 9: 386-389.

Evert RF (2006) Esau's Plant Anatomy, 3rd edn. Meristems, cells and tissues of the plant body - their structure function and development. Wiley-Interscience, New Jersey, 624p.

Fernando JA, Vieira MLC, Machado SR and Appezzato GB (2007) New insights into the in vitro organogenesis process: the case of Passiflora. Plant, Cell, Tissue and Organ Culture 91: 37-44.
Ferreira DF (2011) Sisvar: A computer statistical analysis system. Ciência \& Agrotecnologia 35: 1039-1042.

George EF, Hall MA and Klerk GJ (2008) Plant Propagation by Tissue Culture. Plant, Cell, Tissue and Organ Culture 93: 353-355.

Häsler J, Wüest J, Gaspar T and Crèvecoeur M (2003) Long term in vitrocultured plant cells show typical neoplastic features at the cytological level. Biology of the Cell 95: 357-364.

He Y, Guo X, Lu R, Niu B, Pasapula AV, Hou P, Cai F, Xu Y and Chen F (2009) Changes in morphology and biochemical indices in browning callus derived from Jatropha curcas hypocotyls. Plant, Cell, Tissue and Organ Culture 98: 11-17.

Jha TB, Mukherjee P and Datta MM (2007) Somatic embryogenesis in Jatropha curcas Linn., an important biofuel plant. Plant Biotechnology Reports 1: 135-140.

Joshi M, Mishra A and Jha B (2011) Efficient genetic transformation of Jatropha curcas L. by microprojectile bombardment using embryo axes. Industrial Crops and Products 33: 67-77.

Kaewpooa M and Te-Chatob S (2009) Influence of explant types and plant growth regulators on multiple shoot formation from Jatropha curcas. Scientia Asiatica 35: 353-357. 
Kumar N and Reddy MP (2010) Plant regeneration through the direct induction of shoot buds from petiole explants of Jatropha curcas: a biofuel plant. Annals of Applied Biology 156: 367-375.

Kumar N, Vijay AKG and Reddy MP (2011) In vitro regeneration from petiole explants of non-toxic Jatropha curcas. Industrials Crops and Products 33: 146-151.

Leela T, Naresh B, Reddy SM, Adhusudhan NCM and Cherku PD (2011) Morphological, physico-chemical and micropropagation studies in Jatropha curcas L. and RAPD analysis of the regenerants. Applied Energy 88: 2071-2079.

Lodish H, Berk A, Zipursky SL, Matsudaira P, Baltimore D and Darnell J (2000) Molecular Cell Biology. 4th edition, W. H. Freeman, New York.

Misra P, Toppo DD, Mishra MK, Saema S and Singh G (2011) Agrobacterium tumefaciens-mediated transformation protocol of Jatropha curcas L. using leaf and hypocotyl segments. Journal of Plant Biochemistry and Biotechnology 21: 128-13.

Murali KS, Patil M and Maurya G (2011) Commercially viable e process for in vitro mass culture of Jatropha curcas. United States Patent $\mathrm{n}^{\circ}$ US 7,932,086 B2.

Murashige T and Skoog F (1962) A revised medium for rapid growth and bioassays with tobacco tissue cultures. Physiology Plantarum 15: $473-497$.

Na H, Kim KW, Kwack Y, Kim SK and Chun C (2007) Comparative anatomy of embryogenic and non-embryogenic calli from Pimpinella brachycarpa. Journal of Plant Biology 50: 344-350.

Nunes C, Pasqual M, Santos DN, Custódio TN and Araujo AG (2008) Diferentes suplementos no cultivo in vitro de embriões de pinhãomanso. Pesquisa Agropecuária Brasileira 43: 9-14.

Pereira RC, Pinto JEBP, Reis ES, Corrêa RM and Bertolluci SKV (2007) Influence of different auxins in the induction and callus growth of Uncaria guianensis J. F. GMEL. Plant Cell, Culture and Micropropagation 3: 69-77.

Qin W, Wei DL, Yi L, Shu LP, Ying X, Lin T and Fang C (2004) Plant regeneration from epicotyl explant of Jatropha curcas. Journal Plant Physiology and Molecular Biology 30: 475-478

Sardana J, Batra A and Ali DJ (2000) An expeditious method for regeneration of somatic embryos in Jatropha curcas L. propagation and in vitro culture. Phytomorphology 50: 239-242.

Sato S, Hirakawa H and Isobe S (2010) Sequence Analysis of the Genome of an Oil-Bearing Tree, Jatropha curcas L. DNA Research 18: 65-76.

Semenza GL (2007) Oxygen-dependent regulation of mitochondrial respiration by hypoxia-inducible factor 1 . Biochemistry Journal 405: 1-9.

Serra AGP, Paiva R and Paiva PDO (2000) Análises bioquímicas de calos formados de explantes foliares de castanha do Brasil (Bertholletia excelsa H. B. K.). Ciencia \& Agrotecnologia 24: 833-840.

Sharma A and Chauhan RS (2010) Repertoire of SSRs in the castor bean genome and their utilization in genetic diversity analysis in Jatropha curcas. Comparative and Functional Genomics 2011: 1-9.

Smith RH (1992) Plant tissue culture: techniques and experiments. Academic, San Diego, 231p.

Stein VC, Paiva R, Herrera RC and Vargas DP (2010) Curva de crescimento e índice de divisão celular de calos de ingazeiro. Revista Ciências Agrarian 53: 159-163.

Sujatha M and Mukta N (1996) Morphogenesis and plant regeneration from tissue cultures of Jatrophacurcas. Plant Cell, Tissue and Organ Culture 44: 135-141.

Varshney A, Sangapillai R, Patil SM and Johnson ST (2011) Histological evidence of morphogenesis from various explants of Jatropha curcas L. Trees 25: 689-694.

Wu J, Liu Y, Tang L, Zhang F and Chen F (2011) A study on structural features in early flower development of Jatropha curcas L. and the classification of its inflorescences. African Journal of Agriculture Research 6: 275-284.

Zuo JR, Niu QW, Frugis G and Cgua N (2002) The Wuschel gene promotes vegetative-to-embryonic transition in Arabidopsis. Plant Journal 30: 349-359. 